\title{
Criminal Responsibility of Children in International Law: A Historical Background
}

\author{
Shohreh Mousavi ${ }^{1}$, Behnam Rastegari ${ }^{2}$, Dr. Rohaida Nordin ${ }^{3}$ \\ ${ }^{1}$ Institut Kajian Rantau Asia Barat (IKRAB), Universiti Kebangsaan Malaysia (UKM) \\ ${ }^{2}$ Faculty of Law, Universiti Kebangsaan Malaysia (UKM) \\ ${ }^{3}$ Faculty of Law, Universiti Kebangsaan Malaysia (UKM) \\ Mousavi.shohreh@yahoo.com,benilaw@yahoo.com, rohaidanordin@yahoo.com
}

\begin{abstract}
Criminal responsibility is a global challenge in children's rights and it is more important than other legal issues in criminal subjects because of its essential role in children's life. The concept of the criminal responsibility has evolved over history and has been interpreted in various ways with the absence of a precise definition by different worldviews. Historical perspective requires putting aside belief systems and exploring the convergence of views from various systems. This paper discovers historical background of criminal responsibility from different schools in international law. The paper concentrates on the religious, social and cultural structures of the international society to explain the traditional concept of criminal responsibility. This paper demonstrates exist of different definitions of criminal responsibility in international law before and after 18th century. At the end in the conclusion this article discusses the history of the criminal responsibility as an indication of the growing exertion of the rights of the child in international law.
\end{abstract}

Keywords: criminal responsibility, children's rights, international law.

\section{INTRODUCTION}

Traditional concepts of criminal responsibility in the past have been based upon cultural perspective and pressures, as well as the nature of the offender from within the community. Due to this fact, the literature concerned with criminal law is often infused with ideas drawn from moral philosophy and philosophy of action. The work of moral philosophers has exerted an extraordinary influence on the criminal lawyer's notion of criminal responsibility. Even if they later broadly acknowledge assistance from cultural or psychological theories, most accounts of responsibility start from there. The moral basis is found in the four principles under which fault is ascribed to persons for their behaviour: accountability, fair opportunity, answerability and justification or excuse (Celia Wells, 2001, p.64-65).

The concept of criminal responsibility should be related to the age at which children are able to understand the consequences of their actions that is another basic principle enshrined in international law. The criminal responsibility in the broadest sense can be considered in a unified or coherent body of international law. Different meanings relating to the criminal responsibility have utility for different purposes and there is reason to decide upon one meaning as the right one. An important element in determining the criminal responsibility is identifying the age of the child. International law relating to children is best understood by considering at the outset what we mean when we talk about childhood and children's rights (Van Bueren,1998,p.33). The two different periods of international law have important role in the history of science developments of criminal law particularly in the criminal responsibility in international law. The characteristics of the criminal responsibility in two different periods of international law, the period prior to the eighteenth century and period following the eighteenth century, will be discussed below.

One of the basic concepts of law particularly criminal law is the concept of criminal responsibility. Responsibility is the bridge between crime and punishment. The meaning of criminal responsibility is a relatively new meaning of children's rights. In reality, meaning of criminal responsibility is fundamental issues of the children's rights. In the first place, will be tried to brief introduce of definition of responsibility and finally definition of civil responsibility and criminal responsibility in related to the international rights of children. 


\section{DEFINITION OF RESPONSIBILITY}

Responsibility is described in lexicons as accountability and frequently correlates responsibility with duty and anything which makes a person responsible. Such an interpretation of the term cannot express the various concepts of responsibility. Responsibility is the obligation to answer for the acts committed and to repair any injury caused. To understand the actual meaning of responsibility, the existence of commitment and duty should be established by the competent authority addition to other conditions and factors that include:

i. The existence of a duty to perform or refrain from committing actions that may be contrary to legal regulations and social relations.

ii. $\quad$ Being informed of the existence of duties as it is not possible to recognize a person as responsible when they have no knowledge of the existence of duties or responsibilities. Not being able to comprehend the existence of duties and responsibilities may be the result of rational and emotional disabilities.

iii. The ability to perform in compliance with duties and responsibilities. Incapacity and disability in the person required to perform in accordance with duties or responsibilities may be the result of social or personal factors (Shojaei, 2008).

The conditions of responsibility are rationality, awareness, authority and physical capability. The basic elements of responsibility vary based upon the time period, the society, the situation and a person's sex. The existence of such distinct perceptions of responsibility in other regards accounts for distinctions drawn concerning the age of responsibility. The concept of responsibility applies to every wrongful act of a person and entails the responsibility of that person, which maybe passive in nature, such as refraining from certain actions in a manner contrary to the best interests of society (Shojaei, 2008).

Yet the concept of responsibility often serves as a trapdoor rather than the safeguard for which it is intended in the justice approach. Instead of insuring freedom from state intrusion, its meaning can become indistinct and may legitimize social control over children whose true responsibility is questionable. Even where underlying moral responsibility is missing, the effects of moral condemnation and punishment follow. At the cost of individual liberty, moral legitimacy, and justice, the public's conscience is relieved and authorities' effective social control is consolidated. Paradoxically, the welfare approach shares some of the same troublesome consequences. The two approaches may appeal to different conceptions of children's rights, but neither communicates a clear role for societyat-large, both bring the weight of problems down upon individual children and families. Such intrinsic flaws leave both the justice approach and the welfare approach as difficult models (Cipriani, 2009,p.17). The concept and meaning of responsibility is divided into civil and criminal responsibility. Discussions in the follows sections are on the two types of responsibilities:

\subsection{Definition of the Civil Responsibility}

Civil law evolved from Roman law, based on a written 'civil code'. Civil law was adopted in France after the French Revolution in 1789, referred to as the Napoleonic Code, and covered matters of private law, including:

i. $\quad$ The legal attributes of a person (e.g.: name, age of majority)

ii. $\quad$ The relationship between individuals (e.g.: marriage, adoption, parentage)

iii. Property (e.g.: possession, land boundaries)

iv. The legal institutions governing or administering these relationships (e.g.: wills, sales, leases, partnerships)

Through plain language and the specific nature of each regulation, civil codes are intended to be easy to understand and apply. It does not rely on precedent to the same extent as common law (Common Law and Civil Law,p.3).

Liability is one of the most significant words in the field of law and attributes legal responsibility for one's acts or omissions. Failure of a person or entity to meet that responsibility leaves him/her/it open suit for any resulting damages or a court order to perform (as in a breach of contract or violation of statute). In order to win a lawsuit the suing party (plaintiff) must prove the legal liability of the defendant if the plaintiff's allegations are shown to be true. This requires evidence of the duty to act, the failure to fulfil that duty, and the connection (proximate cause) of that failure to some injury or harm to the plaintiff. Liability also applies to alleged criminal acts in which the defendant may be responsible for 
his/her acts which constitute a crime, thus making him/her subject to conviction and punishment (Gerald and Kathleen Hill).

Responsibility applies to the physical or mental state of an individual who is bound by law to do something which may be enforced by action. This liability may arise from contracts either express or implied, or in consequence of torts committed (Liability-Dictionary Definition and Overview ,2003). Civil responsibility applies to the damage of objects under the protection of another person, as well as on the violation of obligations by an individual arising from contracts. Civil responsibility allows the person injured to apply for compensation, for example a person seeking damages for injuries incurred as a result of an automobile accident.

\subsection{Definition of the Criminal Responsibility}

Although in the past half century numerous studies have been completed concerning criminal responsibility, research concerning criminal responsibilities is far from complete and also issues, such as the concept and meaning of criminal responsibility, have not been completely resolved. The lack of clarity regarding the concept and meaning of criminal responsibility is an important element that need to be examined. Generally, criminal responsibility applies to the violation of others' rights. Criminal responsibility establishes a support system for the rights of individuals and defends the community. Although the legal definition of criminal responsibility has never been expressed clearly, the concept is necessary to respond to criminal phenomenon. Criminal responsibility establishes the basis for the prosecution of criminal offenses committed under criminal law, as well as the basis for penal sanctions against the offender as the responsible person.

For example, in order for an act to be criminal under the Law of England, the following conditions must be fulfilled:

i. The act must be done by a person of competent age.

ii. The act must be voluntary, and the person who does it must also be free from certain forms of compulsion.

iii. The act must be intentional.

iv. Knowledge in various degrees according to the nature of different offences must accompany it.

v. In many cases the terms malice, fraud, or negligence enter into the definition of offences.

vi. Each of these general conditions (except the condition as to age) may be affected by the insanity of the offender (Fitzjames Stephen,1996,p.97).

Thus for judicial authorities, it must be clear that the offender has intellectual and physical growth and ability or will and authority that could create causal relationship between the committed person and the act which he has done. The resulting elements of criminal responsibility are rationality, awareness, authority and physical capability. Nowadays, these elements are essential to the age of responsibility.

\section{THE HISTORICAL BACKGROUND OF CRIMINAL RESPONSIBILITY OF CHILDREN IN INTERNATIONAL LAW}

The two different periods of international law have important role in the history of science developments of criminal law particularly in the criminal responsibility in international law. The characteristics of the criminal responsibility in two different periods of international law, the period prior to the 18th century and period following the 18th century, will be discussed below.

\subsection{Historical Background of Criminal Responsibility Before the 18th Century}

Before the 18th century in judicial systems there are two purposes of punishment in these systems. First, the purpose was to improve of offender so they believed that punishment has ethical aspect and second purpose was threaten and warning aspect of punishment therefore they believed that punishment is inspired by social security. According to the collective aspect criminal responsibility and lack of attention to offender's personality and identity (objective aspect of criminal responsibility) before the 18th century, two important features created about the criminal responsibility after the 18th century that is includes: individually criminal responsibility and personally criminal responsibility. In this part the researcher will be examining two important aspects of criminal responsibility before the 18th century. 


\subsubsection{Collective Aspect of Criminal Responsibility}

The most important feature of criminal responsibility in this period was that it was collective in nature (Sanei, 1993, p. 46). Collective criminal responsibility meant that the criminal responsibility of a person was attributed to his family or his clan, as the person was considered part of the whole. Collective responsibility, as a principle, was generally accepted in the community. In effect the responsibility of the individual offender resulted in, his relatives also being indicted. The idea of collective criminal responsibility was prevalent through the medieval ages. During the medieval period, whenever someone committed an offense against the king, often times the offender and the offender's children were convicted to death as the method sought to remove the purpose of the crime and children were believed to inherit such ideas and actions from their fathers (Naimi, 2003, p.80-111).

\subsubsection{Sub-subsection: Objective Aspect of Criminal Responsibility}

The second important feature of the course of criminal responsibility is the objective aspect. Prior to the eighteenth century there was no attention paid to the offender's mental state, spiritual beliefs or personality in relation to the offense committed, nor was the matter of whether the crime was committed intentionally or unintentionally considered. As a result, prior to the eighteenth century, the objective aspect placed no emphasis on the mental or intellectual elements of a crime in regards to criminal responsibility. Objective aspect of responsibility was common in ancient Rome, Greece and Iran. They believed that someone who committed a crime had caused a stain on the person's soul due to the commission of a sinful act and the person's soul could only be cleansed through the imposition of a penalty ( Naimi, 2003, p.80-111).

\subsection{Historical Background of Criminal Responsibility After the 18th Century}

Historians generally agree that basic reforms to political, social and legal systems began in the 18th century. As a result, discussions typically identify studies of periods following the eighteenth century as contemporary period studies. Some writers believe that the fundamental contemporary concept of criminal responsibility in Europe is attributable to the 18th century. Inappropriate acts of legal entities violated the rights and freedoms of individuals; resulted in penalties consisting of deadly torture and other severe and inhumane punishments; resulted in authoritarian governments; and judicial tyranny regarding verdicts made by judges. Such issues provided a foundation for public protests and intense attacks from lawyers. Social and political upheaval, combined with a desire to improve social, political and legal systems, resulted in the eighteenth century being noted as a period of enlightenment (Naimi, 2003, p.80-111).

In 1766, Beccaria published "Crimes and Punishments," a treatise which was important to the reform movement for criminal law. Beccaria was an Italian scientist who was influenced by French revolutionaries (Saleh Validi, 1986, p.95). Additionally, the first criminal law schools were founded, attracting the greatest legal thinkers and experts of the time. Furthermore, the criminal law issues and principles of criminal responsibility dealt with in the eighteenth century established the foundations for the systems which exist today. The issues considered following the 18th century reforms included the principle of personal criminal responsibility; the mental status of the offender; and the moral responsibility of the offender in relation to the offense committed, which resulted in distinctions being drawn between the average person and children and insane individuals. The 18th century marked the acceptance within international society that determinations of criminal responsibility should be based upon justice and humanity (Naimi, 2003, p.80-111).

\subsubsection{Historical Background from the Perspective of the Main Schools of Criminal Responsibility of Children}

The 18th century has been considered an important point of scientific and social developments, particularly regarding criminal law because before the 18th century, there were cruel and inhuman punishments and most penalties were commonly applied in different societies. Principles such as the principle of collective penalty was included relatives penalty, acquaintances and severe penalty on irresponsible persons such as minors, insane, slaves and even animals which was not consistent with the idea of any human. Lack of attention to the issues of offenders reform and injustices, these reasons were enough for incite feelings of liberals and intellectuals and the subsequent, created different legal schools that each of them had supporters and opponents. Hereunder, we will review scientist's comments about the schools of criminal responsibility and criminal responsibility of children in different schools.

\subsubsection{Criminal Responsibility of Children and the Classical School}


After the French Revolution, liberal ideas began to emerge in traditional institutions of criminal law that led to fundamental changes in perspectives concerning criminal responsibility. The reforms, led by scientists such as Montesquieu and Baccaria, were encapsulated within the Classical School, the history of which is argued by experts to begin in 1748 with the publication of Montesquieu's treatise, "The Spirit of Laws" (Mohseni,2003, p.189).

Criminal responsibility in the Classical school is based upon moral responsibility. They believed that offenders with freedom have chosen to commit a crime and are morally responsible, therefore deserving of punishment. The opinion of the Classical School is that responsibility should be established based upon violations of social and individual contract with full willpower and freedom in contract entered into freely and willfully by individuals. People convey some of their freedoms to the community because the community is able to maintain them and protect them against harm during events and attacks. The conveyance of certain freedoms in return for security requires individuals to obey the rules of the societies. Now if such people breach their duties, they become an enemy of society and society has right take action to punish such individuals, punishment depending upon the degree of the offender's understanding and consciousness (Naimi, 2003, p.80-111). In this school, the age of child was generally 16 years and the status enjoyed exemption from punishment, if the child was considered morally and intellectually deficient to be attributed criminal responsibility. However, if a child was less than 16 years and knowingly and consciously committed a crime, they were held responsible and were not exempt from punishment (Shambayati, 1999, p.39-41).

\subsubsection{Criminal Responsibility of Children and the Neoclassical School}

While the Classical School was not completely advantageous for children, it served as the foundation for the Neoclassical School. Scientists of the Neoclassical School believed that the level of penalty should be proportional to the amount of offender's mental and moral status. Due to this view, children and insane persons are deprived of sufficient mental and intellectual capabilities. Therefore, this school believed that the punishment determined for an offender should be based upon factors concerning the degree of the offender's reason and detection power (Shambayati, 1999, p.39-41).

\subsubsection{Criminal Responsibility of Children and the Positivism School}

The Classical and Neoclassical Schools had taken the first steps of the evolution on criminal law and they had many effects on the laws in countries but these schools were subjected of the severe criticism. The main objection was emphasis on the issues of authority and willpower in these Schools. These were effective for presenting new opinions in this way. Scientist's efforts led to the creation of the Positivism School. Perspective in this School was not related to the perspective of Classical and Neoclassical. Unlike the Classical and Neoclassical Schools, by this school has been denying authority and willpower for human. The Positivism School believed that social responsibility should be utilized instead of moral responsibility. Due to this reason scientists, such as Garofalo, were trying to discover delinquency (Naimi, 2003, p.80-111).

The Positivism School was called "school of oriented algebra" and this School's Scientists in their studies concluded that the crime of the children is dependent on many factors. These factors are causing crimes that include: internal factors (Facteurs endogenes) such as inheritance and external factors (Facteurs exogenes) such as social, cultural factors. School believed that all these factors forced the human to the crime and scientists concluded that the crimes especially of children are dependent to many factors. Thus, in addressing to the causes of crime for children these factors should be considered. This school's sponsors had suggested safeguarding measures for offender children. Therefore, responsibility for children as relative responsibility is based on special perspective of this School and this School argues that the best way to combat of juvenile's crime is the appropriate response with regard to real character of child offenders (Shambayati, 1999, p.44-45).

\subsubsection{Criminal Responsibility of Children and the Schools of Social Defence}

The most important of these Schools was Social Defence School, emerging at the end of the 19th century. In the past, the term 'social defence' was used, but the old meaning of 'social defence' is fundamentally different in relation to its modern meaning. The new meaning of social defence refers to the desire to defend society through the social rehabilitation of re-offenders. The basic idea is that if the community can accept the individual, the individual may be deterred from repeating crimes. The Social Defence School has divided into two distinct branches which differ in regards to criminal responsibility (Ashuri and Najafi Abrand Abadi,1987, p.5-13). 


\section{i. School of Extremist Social Defence}

Filipo Gramatical is viewed as the leader and founder of this Italian school. Gramatical believed that aim of law is promote the individual in society but traditional institutions of the criminal law such as crime, punishment and responsibility, prevented achieving this aim. In addition, of the instead terms of 'crime' and 'responsibility' offenses should be perceived as signs of an anti-social mode. Anti-social mode represents the true character of the offense committed. The terms of social defence's actions and social defense rights should be utilized instead of penalties and criminal law. This School argues that punishment and criminal responsibility are not consistent with the ultimate goal of criminal law, which is to reach perfection (Naimi, 2003, p.80-111).

The Extremist's viewpoint is that children, as delinquent adults can show signs of anti-social mode. Anti-social mode is the result of social defence's actions in children. Particularly if society accept that reform and rehabilitation of children's incompatible with society is more easier than reform and rehabilitation of adult's incompatible and also rehabilitation of these kind of children is important and useful more than rehabilitation of adult.

\section{ii. School of Moderation Social Defence}

Originating amongst French scholars, the Moderation Society Defense School promotes the moderation method. This School, despite its opposition to the traditional penal system, did not believe that social defendable rights should be utilized instead of criminal law. The School suggests that the existing criminal law under the protection of various sciences should be going to the direction of perfection and emphasised the committed character, and argues that the reactions of the society against the committed should be based on his features. This school was opposed to the use and implementation of severe criminal penalties as the only tool to prevent crime. In fact, the content of Society Defence school was manifested as led to revision in the criminal system (Ashuri and Najafi Abrand Abadi,1987, p.93-107).

Also, it is necessary to give attention to the actual character of children. Ideas directly related to this School relate to the implementation of protective and training measures for children. Following the end of the authoritarian period, the change in social defence should lead to the reform of prisons and the legal regime governing children offenders. Thus, after the elapse of authoritarianism period Western Europe has been freed and by the social defense has been changed system of prisons, the governing policy of juvenile offenders. The new wave of these reforms later expanded in other countries (Mohseni, 2003, p. 265-275).

\section{CONCLUSION}

In history before the 18th century, many examples of these cases were recorded. For example, if the branch of tree was caused injury to someone, it was reasoned that a portion of the tree should be cut and if a human was killed by an animal, the animal was tried in court and killed as a result of the court's order. The prevalence of such practices continued until the French Revolution 1789. As mentioned earlier, there was no distinction between the individual or collective identity of the perpetrators of crimes; no attention was paid to the condition of the offender's age, mind and personality; and there were not enough reasons for punishment (Shambayati,1999, p.25).

The 18th century is accepted as a watershed in the history of science developments of criminal law particularly in the criminal responsibility in international law. Today, behaviour of an anti-social nature is described as 'criminal' to show society's disapproval. As a result, laws tend to use the phrase 'age of criminal responsibility' in two different ways:

i. as a definition of the process for dealing with an assumed offender, the series of ages specifies are the exemption of the adult system of trial and punishment. The majority developed States such as Sweden, Canada and Germany have special juvenile justice systems in parallel to the adult criminal justice system. Now, the children's rights are essentially welfare-based and deal with children as in need of compulsory measures of treatment and care. Children are diverted into this system when they have committed what would have been an offense in an adult.

ii. as the physical ability of a child to commit a crime. Thus, children are deemed unable of committing some sexual or other acts requiring abilities of a more mature quality (Kamble and Vishwapriya, 2010,pp.,11-12). 


\section{ACKNOWLEDGEMENTS}

The researchers would like to express their gratitude to Universiti Kebangsaan Malaysia for sponsoring this study under the Project Code: UKM-UU-05-FRGS0082-2009 and UKM Fellowship Research University (Zamalah Research Universiti).

\section{AUTHOR NOTES}

Shohreh Mousavi is a Post Graduate student for Master degree at the Institute of West Asian Studies (IKRAB), Universiti Kebangsaan Malaysia (UKM). She can be contacted at: mousavi.shohreh @yahoo.com. Behnam Rastegari is PhD candidate for Public International Law at the Faculty of Law, Universiti Kebangsaan Malaysia (UKM). He can be contacted at: beni law@yahoo.com. Dr. Rohaida Nordin is a senior lecturer at the Faculty of Law, Universiti Kebangsaan Malaysia (UKM). She can be contacted at: rohaidanordin@ukm.my.

\section{REFERENCES}

Ashuri, M., \& Abadi, A. H. N. A. (trs.). (1987). Marc Ancel, Social Defence. Tehran: University of Tehran.

Bueren, G. V. (1998). The International Law on the Rights of the Child. The Hague: Kluwer Law International.

Cipriani, D. (2009). Children's Rights and the Minimum Age of Criminal Responsibility (A Global Perspective). Farnham: Ashgate.

Common Law and Civil Law. www.canadiana.ca/citm/specifique/lois_e.rtf (05 July, 2012).

Hill, G., \& Hill, K. (Eds.). The Free Dictcionary (Legal) Farlex http://legal-dictionary.thefreedictionary. com/ (05 July 2012).

Liability-Dictionary Definition and Overview. (2003). http://www.wordiq.com/liability (05 July 2012).

Mohseni, M. (2003). doreh hoghoghe jazaye omomi (Public Criminal Law Series). Tehran: Ganje Danesh.

Naimi, L. (2003). Masoliyate Keyfari Atfal az Didgahe Makatebe Mokhtalef(Criminal Responsibility of Children from Perspective of Different Schools). Journal of Jurisprudence and Islamic Law, 32, 80-111.

R.M.Kamble, \& C.Vishwapriya. (2010). Cyber Crimes and Information Technology. Nalsar Law Review 5(1), 1-188 http://www.nalsar.ac.in/pdf/Journals/Nalsar\%120Law\%120Review-Vol.\%205.pdf (05 July 2012).

Sanei, P. (1993). Hoghoghe Jazaye Omomi(Public Criminal Law). Tehran: Ganje Danesh.

Shambayati, H. (1999). Bezehkarie Atfal va Nojavanan(Children and Youth Delinquency). Tehran: Pajhang.

Shojaei, B. (2008). Sharayete Sene Masoliyat va Taklif (Condition of the Age of Responsibility and Religious Duty). Etemad http://www.aftabir.com/articles/view/social/law/c4c1229249160 age p1.php (05 July 2012).

Stephen, J. F. (1996). A History of the Criminal Law of England (Vol. 1). London: Routledge.

Validi, M. S. (1986). Masoliyate keyfari (Criminal Responsibility). Tehran: Amir Kabir.

Wells, C. (2001). Corporations and Criminal Responsibility. New York: Oxford University Press. 